\title{
E.J. Smit
}

Registrateur PU vir CHO en vroeër hoogleraar in Semitiese Tale

\section{ABSTRACT}

The article, part 1 of the Stoker Lectures for 1984, deals with Old Testament world view and anthropology. After briefly referring to the fact that Old Testament thought cannot be regarded as being "logical" in the Greek concept of the thought, he also points out that old Testament thought is opposed to mythopoeic thought, concluding that it can most accurately be typified as being empirico-logical in nature (Albright). This way of thinking is further exemplified as containing logic implicitly and not in formal categories.

It is also pointed out, in a fuller discussion of the Hebrew conception of the world, that it was influenced of necessity by surrounding nations. The view of the world in which the Old Testament writer lived could not materially be distinguished from his religious views, and likewise it could not be distinguished from the views held in general by Eastern Antiquity.

The same views could be applied in looking at the anthropology of these people, although Old Testament anthropology does oppose the mythological view of man held by Eastern Antiquity. This is exemplified, for example, in the Old Testament view of the division, in principle, between God and man, man's dependency on God, and man's position in the hierarchy of creation, keeping in mind his responsibility in the personal sense. The concept of death, as opposed to various views held in Mesopotamia, Egypt and among mythopoeic thinkers, also developed to the point where it was regarded as being a natural part of life.

The article ends with a discussion of views of time and history as based on these concepts of the world and of man, with time seen as a mere instrument in the salvational plan of God with the world, and overall God being seen as central to man and his world. 
INLLIDING

Om iets oor die wèreldbeeld van die Ou Testament te sè is wel 'n vererende versoek maar ' $n$ versoek wat nogal heelwat eise stel - eise waarvan ek mar al te bewus is dat ek in my huidige werksomstandighede nie daaraan ten volle reg kan laat geskied nie. Ek dank u nieternin dat ek in hierdie deurlugtige gehoor iets oor die onderwerp ıag sê.

Ek meen dat ek tog iets oor die onderwerp kan sè, hoewel ek dadelik die warskuwing daarby moet voeg dat ek slegs breë lyne sal trek en nie veel in besonderhede sal ingaan nie - iets waarvoor ek my in my huidige situasie nie die luukse kan veroorloof nie, want geleerdes wat dit probeer doen het, het met "kurze Einführungen" van etlike volumes geëindig; en iets waartoe ek, dink ek, nie heeltemal meer in staat is nie, omdat ek ' $n$ paar jaar lank al die aktiewe beoefening van die verskillende dissiplines ter sake moet ontbeer en veral die jongste literatuur daaroor nie altyd kon byhou nie.

Tersaaklike dissiplines vir die behandeling van hierdie onderwerp is velerlei. Die onderwerp kan moeilik behandel word sonder 'n vergelyking met die verwante beskouinge van Israel se buurlande en die ontwikkeling van die gedagtegang en denkwyse wat by hulle plaasgevind het, hulle godsdiens, ' $n$ beskouing van hulle literatuur en 'n wardeskatting van die verskillende literatuursoorte waaruit gedagtes in hierdie verband gerekonstrueer word; verder 'n filologiese studie van die woorde wat in die Ou Testament gebruik word om die begrippe waarom dit gaan, mee uit te druk, waarby etimologie en semasiologie en vergelykende filologiese studie met die ander kontemporère Semitiese tale 'n geldige ondersoekmetode sou wees; ook 'n kanonies-eksegetiese studie van die uitsprake in die $\mathrm{Ou}$ Testament en 'n openbaringshistoriese evaluering daarvan. 'n Dieptebespreking hiervan moet $u$ vandag ontbeer. Dit is egter nodig om aan te dui hoe kompleks hierdie tipe ondersoek is, nie om daarmee ' $n$ klop op die skouer te probeer verdien nie maar om daarmee 'n maatstaf te probeer gee vir die beoordeling van die literatuur wat hieroor handel, en om ' $n$ waarskuwing te rig dat menige skrywer our hierdie onderwerp sy hand in in eensydige benadering oorspeel het. Eenrigtingondersoeke kan wel dienstig wees om uiteindelik 'n geheel op te bou, maar dit kan nie maklik tot omvattende geldige konklusies lei nie. 
Juis in hierdie verband wil ek graag 'n paar breë lyne in die onderverdelings van die onderwerp aandui. Meer as breë lyne kan dit nie wees nie, maar ek hoop dat dit duidelik mag wees uit die wyse waarop dit aangebied word, dat wanneer ons met die $O u$ Testament te make het, ons die Ou Testament as deel van die Bybel, die Woord van God, moet sien; dat die Ou Testament bestaan uit 'n aantal boeke wat elk sy eie ontstaansgeskiedenis het; dat selfs identiese woordgebruik steeds eksegeties teen ' $n$ bepaalde kontekstuele agtergrond gesien moet word en dat ten slotte die eenheid van die Ou Testament in sy openbaringsen verkondigingsinhoud lè. Veral laasgenoemde maak dit dus vir my wel moontlik om iets oor die onderwerp te sè, al merk $u$ al dat dit in beklemtoning sal afwyk van die populère uitsprake in hierdie verband, wat nogal geneig is om die nadruk te lè op dit wat op pikante wyse van 'n moderne Westerse beskouing verskil.

Dit lyk of dit die begryp van die onderwerp sal dien as ons agtereenvolgens iets sè oor die denkwyse van die Ou Testament, dan oor die wèreldbeeld of wèreldbeskouing, die mensbeskouing en ten slotte iets oor die tyds- en geskiedenisbeskouing.

\section{DIE DENKWYSE VAN DIE OU TESTAMLNT}

Die bekende prof. W.F. Albright (1965:68) skryf dat hy met in algebraïese meetkundige in 'n diskussie geraak het oor die probleem van die denkwyse van die Ou Testament. Na 'n deeglike bestudering van die tekste van die Ou Ooste en van die Ou Testament moes hierdie geleerde erken dat daar in hierdie tekste geen formele logika te vinde was nie. Elders verduidelik Albright (1965:84) wat liy hieronder verstaan: 'n totale ontbreking van die Griekse sistematiese redenering; geen sistematiese analise van voorveronderstellinge nie, geen hiërargiese klassifikasie van verskynsels nie, geen formele postulate of deduktiewe sillogismes nie; ook geen definisie van abstrakte terme nie en daarom ook geen geformuleerde geloofsbelydenisse nie

Waar staan ons dan met die denkwyse van die Ou Testament?

As ons sou sè dat ons in die Ou Testament nog nie formele logika aantref nie, lewer ons daarmee slegs in historiese of kultuurhistoriese uitspraak, 
want dit is seker dat die literatuur van die Bybei vroeër gedateer moet word as enige Griekse literatuur wat as filosofies of "logies" bestempel kan word.

Vir praktiese doeleindes kan die Ou Testanent gedateer word tussen die geskrifte van die Ou Ooste en diè van die Griekse era van intellek, wat in die vyfde eeu voor Christus 'n aanvang neem. Plato en Aristoteles het eers in die vierde eeu voor Christus geskryf (Albright, 1965:86).

Teenoor die Griekse logiese deıke word gewooulik gestel die "primitiewe denke", nader gespesifiseer as die "mitopoeiïese" denkwyse, dit wil sé die mitemakende denke (Frankfort e.a., 1951:7) of die protologiese denkwyse (Albright, 1965: Passin).

H. en H.A. Frankfort (Frankfort e.a., 1951:19 e.v.) omskryf die elemente van die mitopoeiïese denke in die volgende terme, waarvan ons hier slegs 'n kort oorsig gee:

- die gebrek aan onderskeiding tussen subjektiewe en objektiewe kennis:

- die wegval van die kontras tussen werklikheid en voorkoms (drorne kom net so reëel voor as indrukke in 'n toestand van wakker wees):

- geen skerp onderskeiding tussen die lewendes en die dooies nik;

- die saamval van 'n simbool en dit wat dit simboliseer;

- die identifikasie in die figuur van pars pro toto: 'n haarlok verteenwoordig byvoorbeeld die werklike mens;

- die naam van ' $n$ persoon is tegelyk die identifisering van die persoon;

- daar is geen onderskeiding tussen ' $n$ werklike en 'n simboliese handeling nie; 
- die substansiëring van konsepte (bv. Ma'at: geregtigheid, waarheid in die Egiptiese mitologie is ook die godin Ma'at voorgestel as ' $n$ veer);

- in die vraag na die kousaliteit word gesoek na die wie en nie na die hoe of waarom nie: in natuurlike gebeurtenisse word nie gesoek na 'n onpersoonlike regulerende wet nie maar na 'n bedoelde wilsbeslissing wat die gebeurtenis reguleer, byvoorbeeld dat siekte deur ' $n$ bepaalde sonde of oortreding veroorsaak word. Daarom word die gode as gepersonifieerde natuur- of kultuurkragte voorgestel as verklaring van die kousaliteit van bepaalde gebeurtenisse.

Teenoor hierdie denke staan die denkwyse van die Ou Testament. Dit word gou duidelik dat die Ou Testament sterk afwysend staan teenoor die mitologie. Trouens, sekere gedeeltes van die Ou Testament word deur sommige geleerdes as 'n doelbewuste polemiek teen die mitologie gesien. Tog ontbreek in die Ou Testament die formele logika (vide supra) en word sekere mitologiese figure en terme in die Ou Testament gebruik.

In die algemeen kan ons met Albright (1965:92 e.v.) saamstem dat die denkwyse van die Ou Testament as 'n empiriese logika beskryf kan word. Dit stel Albright teenoor die pogings van andere om hierdie denkwyse te verklaar. Die opmerklikste hiervan is die poging om die andersheid van die denkwyse van die Ou Testament uit die struktuur van die Hebreeuse taal te verklaar, en daarmee enigsins verwant is die bekende poging van Thorleif Boman in sy Das hebraische Denken im Vergletch mit dem grlechischen, waarin hy stel dat Hebreeus ' $n$ dinamiese taal is teenoor die Grieks wat 'n statiese taal is; die Hebreeus is temporaal (in terme van tyd) en die Grieks spasiaal (in terme van ruimte). Dikwels word hierby gevoeg dat die Hebreeuse denke konkreet is, hom konkreet uitdruk, terwyl die Griekse met abstraksies en abstrakte redenasies werk (Smit, 1976:6). Hoewel hierdie poging van Boman heelwat verdienstelike aspekte het, hou dit tog nie genoeg rekening inet die feit dat bepaalde woorde as gevolg van verskillende semantiese velde nie sonder meer met 'n regstreekse ekwivalent in enige ander taal oorgesit kan word nie en verder dat wat in een taal gesê word, al is dit met behulp van ander woorde of hoogstens op 'n omskrywende manier, steeds adekwaat of feitlik adekwaat in 'n ander taal oorgesit kan word. 
Die empiriese logika van die Ou Testament verklaar Albright dan as 'n denkwyse waarin die logika implisiet voorkom en nie in formele kategorieë uitgedruk word nie. Daarmee hang saam die "ontmitologiserende" trek van die Ou Testament. So kan die mitologiese name en vorme wel in die Ou Testament figureer maar dan steeds as 'n negatiewe konteks waarteen die positiewe verkondiging van die almag en majesteit van Jahweh, die God van Israel, geprojekteer word. Sommige, veral poëtiese, gedeeltes van die Ou Testament kan slegs sinvol verstaan word wanneer ons die mites waarteen dit polemies gerig is, ken. Verder kan ons se dat die mitologiese figure en uitdrukkings veral in gedigte as 'n kragtige poëtiese element aangewend word. 'n Stilistiese ontleding van bekende mites. veral die Ugaritiese naas die Babiloniese en Egiptiese, gee vir ons duidelike aanwysings om die poëtiese styl van baie van die Ou-Testamentiese gedigte beter te begryp (Vgl. ook Childs, 1962:72).

Maar die mitopoeiïese denkwyse ontbreek geheel en al in die Ou Testament. Die ontmitologisering wat in die Ou Testament voorkom, het hom van die mitologie heeltemal ontworstel, al moet ons verwag dat dit as ' $n$ proses nie in alle besonderhede ewe duidelik na vore kom nie. Veral hierdie twee samehangende elemente van die denkwyse van die $\mathrm{Ou}$ Testament, $n l$. die progressiewe ontmitologisering en die aanvaarding van éên God as denkuitgangspunt, het begryplikerwys 'n bepalende invloed gehad op die siering van die Ou Testament op die wêreld en op die inens.

\section{DiE WéRELIJBESKOUING VAN IDE OU TLSTAMEN'}

Hoewel dit nie te ontken is nie dat die beskouing van die Ou Testament in verband met die wêreld waarin hy leef, verskillende spore van die wèreldbeeld van die omringende volke dra en dat daar figure, terme en beelde in voorkom wat sterk aan die mitologiese voorsteilinge van sy buurvolke herinner, is ons daarvan oortuig dat hierdie beskouing van die Ou Testament pririsipieel verskillend is van dié van die omringende volke en stem ons saam met Vriezen (1966:31) dat ons moet praat van wèreldbeskouing - "over het wereldbeeld spreken wij niet, dit is zonder meer geheel oud-Oosters".

Wanneer daar 'n opsomming gegee word van die uitdrukkings wat in die Ou Testament gebruik word om die wèreld mee te beskryf soos Edmond 
Jacob (1961:144 e.v.) dit doen, lyk dit aanvanklik na 'n blote meganiese en onsinvolle opsomming van teksuitsprake. $H y$ sè byvoorbeeld (1961:144-145): "The cosmological conceptions of the Israelites do not seem to have been directly influenced by their religious beliefs. In a general way the Israelites shared the ideas common to the ancient world, conceiving the world as a three-storey building, the heavens above, the earth below and the waters under the earth (Ex. 20:4), a representation which rests as much upon observational data as upon certain mythical concepts".

Hy beskryf die uitsprake dan verder: die uitspansel is ' $n$ soliede konstruksie, wat rus op pilare, wat die hemelse oseaan van die aardse afskei, en die wegneem daarvan bring die toestand van die oerchaos weer terug. Bokant die hemelse oseaan is ' $n$ kamer gebou wat deur pilare gesteun word en waar God sy troon gevestig het, ens., ens.

Wanneer Jacob (1966:146) egter na 'n bespreking van die tekste in verband met Sje'ool sê: "This conception of the world is so little influenced by religion that it was rather an obstacle than an aid to faith. Yahweh was not at the outset the god of heaven and to become so he had to dethrone other deities and it took him several centuries to extend his power over Sheol", dan blyk dit dat die opsomming nie uit "n blote naiwiteit gebore is nie.

Sinvoller is die bespreking van Heinisch (1955:147), wat daarop wys dat die Ou-Testamentiese uitsprake 'n sterk ooreenkoms met dié van die omringende volke vertoon. Hy sè verder: "They were not derived from primitive revelation but simply from appearances. The Biblical writers used current thought as a means to express religious doctrine. In the natural sciences the hagiographers were children of their times. For obtaining profane knowledge God endowed man not with the Bible but with the ability to do research work. And every attempt by 'concordists' to harmonize the details of scientific data with the Bible has resulted in lowering esteem for the inspired Word". Tog bied veral die voorlaaste sin van hierdie uitspraak die probleem dat die openbaringsinhoud van die Ou-Testamentiese uitsprake in die lug hang en dat daaraan nie reg geskied nie. 
'n Baie verdienstelike poging om die beskouing van die Ou Testament uiteen te sit, vind ons by Stadelmann (1970), wat met behulp van etimologiese ondersoek en dan 'n ondersoek na literère uitspraak by Israel en sy buurvolke poog on die drieverdiepingstruktuur van Israel se wèreldbeskouing te verstaan. Die finale slotsom van Stadelmann maak onses insiens tog 'n sprong oor 'n aantal probleme wat, hoewel in sigself nogal aanvaarbaar, nie al die probleme in die verband honoreer nie. Hy sè (1970:182-183): "Yet we do the ancient Hebrews' world view but half justice if we fail to see their basic understanding of the natural order and the manner in which they reacted to the universe following the principles of their religious life. They testify to a profound conviction that nature is created by God and, as sucl,, is visible evidence of his reality and his omnipotence, and of his participation in the affairs of the world. This attitude towards it is revealed in the routine of daily life as much as in moments of crisis. In fact, as their existence as a nation is regarded as an open adventure, and as their own destiny is regarded as that of a Chosen People fitting into a transcendent pattern, so their physical environment derives its significance from its relation to the people, as the stage on which the historical drama of the nation is performed".

Veel sinvoller vind ons die benadering van Vriezen (1966:356,361 e.v.), wat tussen die volgende gesigspunte onderskei:

- Aan die een kant is daar die Ou-Testanentiese wèrelclbeeld, dit wil sè die wèreldsiening wat identies is met dié van die Oud-Oosterse volke en wat onder meer die volgende elemente bevat: die aarde is plat, is omgeef deur die wèreldsee, is rustend op die water; bokant die aarde is die sterrehemel soos ' $n$ koepel, en daarbo bevind die hemeloseaan hom en dáárbo die hoogste heınel, waar die wèreldgod woon. Omdat hierdie beeld gemeengoed van die Oud-Oosterse volke is, het dit nie selfstandige betekenis as deel van die tipiese, die openbaringsinhoud van die Ou Testament nie. "Men kan er daarom niet aan beginnen, dit 'bijbelse' wereldbceld, om der wille des geloofs, apologetisch in bescherining te nemen tegen het moderne natuurwetenschappelijke". 
- Andersyds kry ons die sogenaamde "survivals" uit die mitologie: so byvoorbeeld die chaos in Genesis 1 en 2, waarvan hy sê "(dit) is géén antipode van God, zoals in de oude oosterse mythologieën; de voorstelling heeft haar mythologisch karakter geheel verloren, en is een survival, dat men nog niet heeft los kunnen laten, daar men zich het begrip van een volledig niets niet heeft kunnen vormen"; en byvoorbeeld die stryd van Jahweh met die chaosmonster, "al is de chaos ook de God ter beschikking staande massa, welke Hij ordent naar zijn wil".

* En verder is daar die openbaring ten opsigte van die wereld, dit wil sé die egte wéreldbeskouing van die Ou Testament. Die belangrikste elemente hiervan is die volgende: Omdat God as wêreldskepper gesien word, word die natuur as 'n eenheid gesien en word dit as die volmaakte werk van God geken. Daar word dus 'n baie noue verhouding tussen God en wereld erken; en die eenheid van die mensegeslag, van man en vrou, en selfs van God en mens word baie duidelik uitgedruk. Daarom kan die wêreld nie gesien word as ' $n$ mag wat prinsipieel vyandig teenoor die mens is nie. Die natuurlike gawes en kragte in die wêreld kan ook nie op sigself veroordeel word nie. As gevolg hiervan lé die sonde ook nie in die natuur van die bestaande dinge nie maar lê dit in die wil van die mens. Die Ou Testament gee daarom nie uitdrukking aan 'n tragiese lewenshouding of denkvorm nie, en die lyde in die wèreld word vanuit die gesigspunt van die skuld van die mens gesien. Dualisme en demonisme word op hierdie wyse heeltemal uit die weg geruim. Die verhewendheid, die helderheid, die rustigheid en die warmte van die Ou-Testamentiese wèreldbeskouing is enig in die literatuur van daardie tyd.

Vriezen (1964:44) vat dit elders so saam: "In de oude Oosterse beschaving was de wereld verdeeld tussen vele goden; er was geen eenheid in de wereld, ook geen eenheid van het menselijke geslacht: allen, die buiten Egypte of Mesopotamië leefden, werden door de Egyptenaren, de Assyriërs en de Babyloniërs als barbaren gezien; terwijl de Bijbel leert, dat de wereld een eenheid is, omdat de éne God de Schepper is; ook zijn alle mensen één, want zij stammen allen van enen bloede af en zijn dus wezenlijk aan elkaar gelijkwaardig. De Bijbel doet $-289-$ 
ons leven in één wereld, als mensen één, met éèn God, Die Zijn schepselen door Zijn liefde verbindt en hen gezamenlijk leidt".

Dit is duidelik dat die beskouing van die wèreld waarin hy leef, vir die Ou-Testamentiese skrywer nie van sy Godsbeskouing losgemaak kan word nie; of, anders gestel, dat die sogenaamde wêreldbeeldbeskrywings in die Ou Testament, waarvan daar sommige is wat nie altyd met mekar ooreenstem nie, en hoewel in hoofsaak (bv. die driedelige wèreldbeeld) ooreenstemmend met die wêreldbeeld van die Oud-Oosterse volkere, soms, veral in die poësie, uiters gefragmenteerd voorkom en moeilik tot 'n samehangende geheel geïntegreer kan word - dat hierdie wêreldbeeldbeskrywings nie deel vorm van die tipiese wêreldbeskouing van die Ou Testament nie, en ook nie as betekenisvol vir die Ou-Testamentiese verkondigingsinhoud met betrokking tot die wèreld aangemerk kan word nie.

DIE MENSBESKOUING

Dieselfde uitgangspunte moet ons toepas wanneer ons na die Ou-Testamentiese mensbeskouing kyk. Eers wanneer die breë verkondigingslyn in verband met die mens vasgestel is, wanneer die openbaringsinhoud van die ou Testament as deel van die Bybel nagespeur en vir sy spesifieke polemiese beklemtonings teen die mitologiese agtergrond van Israel se buurvolke afgeweeg is, kan daar na detailontleding van bepaalde uitsprake gekyk word. Vir laasgenoemde sal daar ongelukkig weer nie tyd wees nie. Die breë lyne skep egter onses insiens genoeg moontlikheid om die detailtekste en die verbande in die lig daarvan sinvol te kan ontleed.

Ook wat mensbeskouing betref, moet ons erken dat daar in die Ou Testament enkele gedeeites voorkom wat vir ons onduidelik en daarom problematies is. In hierdie verband word byvoorbeeld veral verwys na Gen. 6 en die problematiek daaromheen en ook byvoorbeeld na so iets soos die samehang tussen sonde en on reinheid en die reinigingshandelinge wat volgens die gegewe voorskrifte voltrek moet word deur skuld- en soenoffers te bring. Daar moet dus aanvaar word dat ons sekere elemente van die Ou Testament, i.c. met betrekking tot sy siening betreffende die mens, nog nie goed begryp nie of dat sekere elemente in die Ou.. $-290-$ 
Testament aan ' $n$ proses van groei en ontwikkeling onderhewig was, wat later in 'n groter, dieper geheelperspektief sy oplossing vind. Die omvang hiervan is egter relatief so gering dat dit nie 'n verandering aan die geheelbeeld mak nie.

Ten opsigte van die geheelbeeld van die mensbeskouing of antropologie van die Ou Testament kan ons sê dat die Ou Testament hom beslis afkeer van die Oud-Oosterse mitologiese siening van die mens.

Die mitologiese mensbeeld word onder andere aangetoon in:

- die plek wat die Inens teenoor die gode inneem, naamlik die van die slaaf wat in blinde gehoorsaamheid die willekeurige grille van sy meester navolg sonder dat hy hoegenaamd begryp waarom dit gaan;

- die plek wat die mens in die natuur inneem, waarby die natuur en sy kragte gepersonifeer word; die natuur is vir hom "n "iy" en nie "n "dit" nie, en die mens se taak op aarde, of hy dit nou sien van die standpunt van die nomadiese bestaanswyse (Akkadies) of die permanente inwonersbestaanswyse (Sumeries) (cf. Pettinato, 1971:47), is dat hy hard moet werk op en in en teenoor die natuur om sy bestaan te verseker;

* die dualistiese oplossing van die probleem van die lyde, byvoorbeeld in die gedig Judbul bel nemeqi ("Ek wil die heer van die wysheid prys"), wat aan die een kant daarop uitloop dat die mens te nietig is om die weë van die gode te verstaan, wat so aanleiding gee tot in tragiese lewenskyk; en aan die ander kant die byna verrassende maar tog ongegronde optimisme, naamlik dat in die donkerste uur die uitkoms naby is, terwyl die verlossing sonder enige motivering uit die lyde as gevolg van siekte en boosheid deur die god Marduk (of watter ander god ook) bewerk word, maar die lyde in die algemeen sterk aan die sonde as corsaak daarvan gekoppel word maar ook aan die willekeurige optrede van gode en demone (cf. Smit, 1973:42-43);

- die gebrek aan 'n oplossing vir die probleem van die dood, waarby Egiptiese godsdiens in sy "klassieke" vorm byvoorbeeld die doodsprobleem opgelos het in 'n byna oordrewe oorgawe aan die $-291-$ 
rituele in verband met die Osirisaanbidding, waarin daar 'n rustigheid of ' $n$ berusting gevind is maar nie ' $n$ werklike oplossing nie. Hierdie oplossing van die Egiptiese godsdiens moet egter ook weer gesien word teen die geheelbeeld van die Egiptiese lewensbeskouing, wat besondere karaktertrekke vertoon wat nie in die Mesopotamiese voorkom nie.

Daarteenoor vind ons by die Mesopotamiërs in 'n groeiende bewuswording van menseregte die siening dat die dood tog inar die straf op (' $n$ ) bepaalde oortreding(e) is. Dit roep die vrae na die waarom van die dood en die soeke na die ewige lewe na vore. Die Gilgamesj-epos, byvoorbeeld, beantwoord hierdie vrae met 'n volslae negatiewe resultaat. Daarom is ' $n$ volgende stap na die uitcrste skeptisisme en pessimisme heeltemal begryplik, soos bv. geillustreer in die bizarre "Tweegesprek van pessimisme": Die heer vertel naamlik aan sy slaaf dat hy iets gaan doen. Die slaaf spoor hom geesdriftig aan om dit te doen, maar dan het die heer alreeds besluit om dit nie te doen nie maar om presies die teenoorgestelde te doen - en die slaaf steun die nuwe besluit met net soveel entoesiastiese argurnerite.

Van die belangrikste elemente van die Ou-Testamentiese mensbeskouing kan ons daarteenoor die volgende noem:

* Die skeiding tussen God en mens. By Israel se buurvolke is die mens uit die gode gebore, is hy van goddelike geslag. In die Ou Testament is daar ' $n$ prinsipiële skeiding tussen God en die mens.

- Die mens is totaal afhanklik van God, is deur God uit die stof van die aarde geskep en is besiel met die lewensasem, wat van God afkomstig is. Die mens is as man en vrou geskep, en aan hulle is die vrugbaarheid as 'n genadegawe van God gegee.

- Met die beskrywing in Gen. 2 word die monogamie as die oorspronklike verhouding tussen man en vrou in die huwelik voorgestel. 
Die mens se algehele afhanklikheid van God word ook uitgedruk in die uitdrukking beeld van God, waaroor die volgende gesé kan word:

- Dit stel die mens in 'n ander verhouding tot God as die dier of enigiets waarvan hierdie beeld nie gebruik word nie.

- Dit druk uit dat die mens in volkome vrede met God leef.

- Dit druk 'n staat van onskuld uit. Die natuurlike oorspronklike geskape verhouding tussen die mens en God word uitgedruk in die onskuldige skaamtegebrek van Adam en Eva vóör die sondeval.

- Dit druk die verhouding van kinderlike aanhanklikheid uit: dit is ' $n$ verhouding van kind tot vader soos dit veral ook na vore kom in die uitdrukking gelykenis van God (vgl. die Hebreeuse woorde selem en demut).

Die mens neem die hoogste plek in die skepping in - weinig minder as 'n goddelike wese (Ps. 8). Die mitologiese voorstelling word verwerp dat die oorspronklike wèreldse chaos uit eie innerlike krag aan gode, firmament, sterre, mense en diere geboorte gegee het. "De verhouding van de gelovige Israëliet tot de aarde en het dier is dus niet antithetisch. Integencleel: de aarde en het dier zijn voortgekomen uit Gods scheppingswerk en ook door Hem zeer goed bevonden (Gen. 1:31). De aarde, met al wat er in is, behoort Hem toe (Ps. 24:1) en looft zijn heerlijkheid. Liederen als Ps. 104 en Job 38vv laten Gods scheppervreugde zien" (Vriezen, 1966:459). Veral ook ten opsigte van die diere word die mitologiese gedagte van oorspronklike gemeenskap van die mens met die dier afgewys (vgl. byvoorbeeld die begin van die Gilgamesj-epos). Die mens is prinsipieel onderskeie van die dier, is bo die dier, het mag oor die dier en beskik oor die dier.

- Die mens is ' $n$ selfstandige wese, deur God uit die stof van die aarde geskep maar besiel met die lewensasem van God en gevorm tot 'n psigosomatiese eenheid. 'n Bespreking van die onderskeid en sameliang van die begrippe nefesj, ruah en lob sou hier van pas -293 - 
wees. Genoeg egter om te sè dat die drie begrippe dikwels naas mekaar en min of meer deurmekaar gebruik word en dat die verskillende funksies wat hiermee hoofsaaklik aangedui word, nie as sodanig begripsmatig van mekaar onderskei word nie.

- Die mens is 'n verantwoordelike wese, is verplig tot gehoorsaamheid aan God. Hoewel die nadruk op die persoonlike verantwoordelikheid eers in die latere profetiese geskrifte na vore kom, terwyl die korporatiewe skuldgedagte in die beskrywing van die vroeëre geskiedenis van Israel sterker beklemtoon word, is die persoonlike verantwoordelikheid van die begin af sterk teenwoordig, terwyl die korporatiewe gedagte veral teen dic agtergrond van die verbondsgedagte tot aan die einde volgehou word.

- Wat die probleem van die lyde betref, slegs enkele opmerkings teenoor wat oor die mitologiese ervaring van die lyde gesè is.

Die samehang van lyde en skuld word in die Ou Testament duidelik geleer (bv. straf vir Eva na die sondeval), dan egter nie as 'n noodlotsamehang nie maar as 'n erkenning van God se geregtigheid.

Die oplossing van die probleem van die lyde vind ons in die Ou Testament langs twee lyne. Die eerste, en so byvoorbeeld in Job, vind ons die oplossing van die waromvraag in die majesteit van God as waarborg vir die geregtigheid van God se wèreldbestuur. Tweedens vind ons die lyn van die versoening en lewensvernuwing deur die lyde as ' $n$ baie prominente lyn in die lewe van die profete van die profeet Elia af tot Jesaja-Jeremia en Esegiël. "De weg tot het heil betekende voor de getrouwe predikers ervan steeds meer een weg van lijden, strijd en ondergang. Het $O . T$. is er vol van, minder dan het N.T. inderdaad, maar toch wel zo duidelijk, dat men mag zeggen: in het $\mathrm{O}$. T. begon het lijden van de 'Ebed Jahwe reeds openbaar te worden" (Vriezen, 1966:115).

Die tragiese en pessimistiese lewensiening van die mens het in die Ou Testament geen plek nie, veral as gevolg van die onblusbare geloof in God. 
- Die dood is vir die mens wat uit die aarde geskep is, iets natuurliks in sy bestaan, hoewel daar onderskeid gemaak word tussen "n "goeie" dood en 'n "kwade" dood, die dood van die opregte as 'n seên en die dood van die onbesnedene as 'n oordeel.

- Die lewe na die dood, of deur die dood heen, is iets wat in die Ou Testament nie sterk na vore kom nie, hoewel dit nadruklik aanwesig is. Wat hieroor gesè word (bv. in die profete en die psalms), dra egter eerder die karakter van 'n uiting van geloofsvertroue op God, wat die lewe gee en bestuur, as van feitelike uitsprake.

BESKOUING OOR TYI) EN (GESKIEUENIS

So lyk die mens en so die wèreld waarop hy lewe. Die lewe is egter nie net 'n momentele gebeure nie, en wanneer die lewe in sy kontinuïteit bekyk word, kom die beskouinge oor tyd en geskiedenis dadelik in die gesigsveld.

Wat die tydsbeskouing betref, kan ons ook weer haas nie eens die onderwerp oopdek nie, laat staan reg daaraan daaraan laat geskied. Genoeg om hiervan te sè dat die Ou-Testamentiese beskouing oor tyd in belangrike opsigte afwyk van die mitologiese. In die mitologiese beskouing "there is no actual distinction in mythical time between the past, the present, and the future" (Childs, 1962:74), terwyl die identifisering van voortyd met eindtyd, Urzeit-Endzeit, in die mite 'n belangrike rol speel. "In opposition to modern historical thinking which understands the future as growing out of the past but never repeating itself, the myth envisages the future as a return to the past. There is a complete disregard for chronological time since there is no true beginning or end" (Childs, 1962:74). Childs sè verder: "This scheme illustrates the mythical understanding of time as moving in a rhythm and being identified with its content. The beginning and end are the times of power par excellence. Time is a measure of this content; therefore, the return to the same content indicates also identity of time" (Childs, $1962: 75)$.

In die Ou Testament speel die kairosbegrip wel 'n rol in woorde soos 'et en mo'ed, maar ook die chronosgedagte, byvoorbeeld in die opeenvolging $-295-$ 
van gebeurtenisse soos uitgedruk in chronologieë en genealogieë en in die beskrywing van die historiese gebeure wat na die toekomstige eskatologiese tyd voortbeweeg.

Hoewel verskeie elemente van die mitologiese Urzeit-Endzeit-patroon skynbaar in die Ou Testament voorkom, bv. die terugkerende chaos, die nuwe skepping, die nuwe verbond en veral die sentrale verlossingsmotief van die nuwe eksodus, is die identifikasie van Urzeit met Endzeit vir die Ou Testament nie gepas nie. Die oorspronklike gebeure is alreeds histories gestempel; die Endzeitgebeure is, hoewel op diè van die Urzeit gebaseer, in wese ' $n$ vernuwing en as sodanig in belangrike opsigte iets verskillends - dis nie 'n blote terugkeer na die begin nie; en die opeenvolging van kairoi in die chronologiese tyd, wat op die eskatologiese tyd uitloop, maak die Ou-Testamentiese tydsbegrip iets totaal verskillends van die tydsbegrip van die mitologie.

Die tyd word ' $n$ blote instrument in die heilsplan van God. Snyman (1974:278) sè: "God beheers en reel die tye. Die tyd is nie 'n selfstandige grootheid naas God nie; Hy gebruik die tyd om sy raadsplan ten uitvoer te bring, en in die proses ag Hy Hom gebonde aan die tyd. Hy oorsien en beheers die opeenvolging van bedelinge; $\mathrm{Hy}$ is die Koning van die eeue". Hoewel die konteks waarbinne Snyman hierdie uitspraak mak, dié is van 'n analise van die begrip tyd in die Nuwe Testament, is hierdie aanhaling spesifiek ook war vir die Ou Testamentiese tydsbegrip.

Ons wil ook hier slegs enkele opmerkings maak oor die geskiedenisbeskouing van die Ou Testament soos dit gekontrasteer word met byvoorbeeld dié van Mesopotamië. Die hoofelemente van die Mesopotamiese geskiedenisbeskouing vat Speiser (1955:72) so saam: Die onsekerheid van die gode bring 'n relativering van die waardes mee; die ritueel is belangriker as die etiek, die vorm belangriker as die inhoud, die koning en die priester is gesamentlik aan die vrees vir die natuur onderworpe, en daarom is hulle onderworpe aan dié vorme wat daarop bereken is om die mens teen die natuur te beskerm. Juis dit het die einde van die vooruitgang in Mesopotamië gebring. 
Daarteenoor staan God in die Ou-Testamentiese geskiedenisbeskouing sentraal. Hy werk sy heilsgeskiedenis uit vir sy volk en deur hulle vir die hele mensheid. Israel is God se volk, en hierdie uitverkiesing bring vir die verbondsvolk ook bepaalde verantwoordelikhede mee (Burrows, 1955: 128-129).

In die gang van die geskiedenis verwesenlik God sy geregtigheid en sy oordele oor die nasies en oor sy volk en bring so sy volk skerp onder die besef van sy heerskappy. Maar $\mathrm{Hy}$ skep ook in die profetiese interpretasie van die geskiedenis die verwagting van die komende heil in verskillende vorme, wat veral by Jesaja uitloop op die eskatologiese verwagting, die verwagting van die laaste dinge.

Sentraal staan egter in die geskiedenisbeskouing van die Ou Testament die uitgangspunt dat God die geskiedenis stuur en lei. Prof. M.A. Beek (1960:8) sê: "De bijbel echter beschrijft de gebeurtenissen als onmiddellijke daden Gods en kent daarom slechts één samenlıang. die gegeven is met het rusten der tijden in de hand Gods".

\section{SI,OT}

Wanneer ons probeer om die beskouinge van die Ou Testament oor bepaalde temas te peil, moet ons onthou dat die Ou Testament as Kanon, as openbaring van God in sekere opsigte 'n voorlopige, 'n nie-finale karakter het en dat al die beskouinge wat ons nagegaan het, in die Nuwe Testament 'n verdieping vind. Sonder dat dit moontlik is om dit uit te put, herhaal ons as voorbeeld die vyf punte waarvan De Groot en Hulst (s.j.) sè dat hierdie dinge in die Ou Testament duideliker en met groter nadruk as in die Nuwe Testament gesè word. In elkeen hiervan spring dit dadelik in die oog hoedat die beskouinge wat ons hier aangeraak het, in die Nuwe Testament verdiep word, aangevul word, nader aan voltooiing gebring word:

- die geweldig-konkrete, die onmiddellike wat die Ou-Testamentiese verkondiging van God kenmerk: "God kan in het Oude Testament zo ontzagwekkend nabij zijn" (347): 
* die onmiddellike wyse waarop die verband gelè word tussen God en die dinge van hierdie wèreld, sodat in die Ou Testament die "Diesseitigkeit" so sterk benadruk word (347-348);

- die groot nadruk op God as Heer van die natuur, as Skepper van alle dinge (348);

- die vooropstelling van God as God van die gerig, met die nasionale as deel van dic voorwerp van die gerig wat sterk beklemtoon word (349);

- 'n groot nadruk op die geheimenis in die verkondiging aangaande God. Hy gee Homself nie prys nie, en diar bly 'n afstand tussen God en die mens bestaan (349).

Om tot ' $n$ verantwoordelike selfstandige beskouing oor die wèreld en die mens te korn moet ons dus aanvaar dat ons nie met die Ou Testament kan volstaan nie maar ook die Nuwe Testament daarby sal moet gebruik. Aan die ander kant lyk dit my tog ook belangrik dat in die eenheid van Ou en Nuwe Testament die onderskeiding en besondere verhouding tussen die twee belangrik is vir diegene wat tekste/uitsprake uit beide wil gebruik om tot bepaalde beskouinge te kom, om so ock die mens en die wèreld en die geskiedenis beter te verstaan. Ten slotte is dit tog waaroor dit in die Bybel as openbaring van God handel: om God te ken, en dan ook die mens, die geskiedenis en die wéreld in hulle verhouding tot God (De Groot en Hulst, s.j.:353).

BRONNELYS

ALBRIGHT, W.F. 1965. History, archaeology and Christian humanism. London : A \& C Black.

BEEK, M.A. 1960. Geschiedenis van Israel. Zeist : W. de Haan.

BOMAN, T. 1959(3). Das hebrEda.ische Denken im vergleich mit dem griechisclien. Göttingen : Vandenhoeck \& Ruprecht. 
BURROWS, M. 1955. Ancient Israel. (In: Denton, R.C. ed. The idea of history in the ancient Near East. New Haven : Yale University Press.)

CHILDS, B.S. 1962(2). Myth and reality in the Old Testament. London : SCM Press.

DE GROOT, J. \& IIULST, A.R. s.j. Macht en wil. Nijkerk : Callenbach.

FRANKFORT, H. et al. 1951(2). Before philosophy. Harmondsworth : Penguin Books.

HEINISCH, P. 1955. Theology of the Old Testament (vert. Heidt, W.G.) Minnesota : The Liturgical Press.

JACOB, E. 1961(2). Theology of the Old Testament (vert. Heathcote, A.W. \& Alicock, J.). London : Hodder \& Stoughton.

PETTINATO, G. 1971. Das altorientalische Menschenbild und die sumerischen und akkadischen Schöpfungsmythen. Heidelberg : $C$. Winter.

SMIT, E.J. 1973. Die betekenis van die ou Nabye Oosterse geskiedenis en kultuur: enkele opmerkings. Perspektief, 12.

SMIT, E.J. 1976. Hebreeus vir teologiese studente - waarom en hoe? Potchefstroom : $\mathrm{PU}$ vir $\mathrm{CHO}$.

SNYMAN, A.H. 1974. Die eindes van die eeue. Potchefstroom : (Proefskrif - PU vir CHO).

SPEISER, E.A. 1955. Ancient Mesopotamia. (In: Denton, R.C. The idea of history in the ancient Near East. New Haven : Yale University Press.)

STADELMANN, L.J. 1970. The Hebrew conception of the world. Rome : Biblical Institute Press. 
VRIEZEN, Th.C. 1964. Het Oude Testament. Groningen : Wolters.

VRIEZEN, Th.C. 1966(3). Hoofdlijnen der theologie van het Oude Testament. Wageningen : Veenman en Zonen. 